\title{
Socionomstuderandes förståelse av begreppet delaktighet
}

\author{
Åsa Rosengren, Eivor Söderström, Arla Cederberg, \\ Bettina Brantberg-Ahlfors och Ingmar Sigfrids
}

\section{ABSTRAKT}

Relationen mellan individ och samhälle är mycket central inom socialpedagogiken. I denna relation blir begreppet delaktighet relevant. Begreppet ges en bred och varierande innebörd i litteraturen, och därav väcktes intresset att studera hur socionomstuderanden förstått begreppet i sina examensarbeten. Artikeln grundar sig på en kvalitativ dokumentstudie av 36 examensarbeten. Stommen för innehållsanalysen utgjordes dels av dimensionerna deltagande, aktörskap och tillhörighet i begreppet delaktighet (Nivala och Ryynänen 2013), dels av de fyra socialpedagogiska kunskapsfälten (Madsen 2006). Resultaten visar att aspekterna som berör deltagande och tillhörighet i begreppet delaktighet främst är relaterade till ett klientperspektiv dvs. vad dessa betyder ur klientens synvinkel. Aspekterna som tangerar aktörskap begränsas till ett professionsperspektiv dvs. hur professionella i olika verksamhetsmiljöer kan stöda och stärka klientens aktörskap. Bland de examensamensarbeten som granskades finns det en stark anknytning till delaktighet på den individuella, relationella och institutionella nivån, medan kopplingen till delaktighet på den samhälleliga nivån är svag.

Nyckelord: socionomstuderande, examensarbete, delaktighet, socialpedagogik 


\section{ABSTRACT \\ SOCIAL SERVICE STUDENTS UNDERSTANDING OF THE CONCEPT OF PARTICIPATION (DELAKTIGHET)}

- The relationship between the individual and the society is very central in social pedagogy. In this relationship, the concept of participation (delaktighet) becomes relevant. In literature the concept is given a broad and varying meaning and therefore an interest was aroused to study how social service students understood the concept in their degree thesis works. This article is based on a qualitative document study of 36 degree theses. The basis for the content analysis was the dimensions of taking part, agency and belonging in the concept (Nivala \& Ryynänen 2013) and the four knowledge fields of social pedagogy (Madsen 2006). The results indicate that the aspects concerning taking part and belonging in the concept are mainly related to a client perspective. The aspects related to agency are limited to a professional perspective, i.e. how professionals can support and strengthen clients own actorship. In the degree theses examined, there is a strong link to the concept of participation at the individual, relational and institutional levels, while the connection to the concept at societal level is weak.

Key words: social service students, degree thesis, participation, social pedagogy

\section{Inledning}

agens samhälle står inför stora sociala utmaningar både lokalt, regionalt, nationellt och globalt. Miljöhot, globalisering, digitalisering, urbanisering, migration och omvandling av välfärdspolitiken utgör exempel på nutidens samhällsförändringar som påverkar välfärdsstater runt om i världen (Sjöberg \& Turunen 2018). I detta sammanhang lyfter Abrahamsson (2011) fram vikten av att se den lokala utvecklingen i ljuset av globaliseringen, eftersom olika samhällsproblem runt om på jorden kan få omedelbara verkningar på lokal nivå. Globaliseringen har enligt honom fått lokala uttryck i dagens samhälle.

De aktuella samhällsförändringarna får också följder för individers vardagsliv. Den finländska forskningen (Blomgren, Hiilamo, Kangas, Niemelä 2012; Karvonen, Martelin, Kestilä, Junna 2017; Kestilä \& Karvonen 2019) visar att fördelningen av hälsan och välfärden blivit allt mer ojämlik inom befolkningen i Finland. Barns och ungas välfärd, långtidsarbetslösheten, 
de funktionshindrades och äldres situation är områden som kräver stora insatser för att förebygga och motverka marginalisering och exkludering (Karvonen \& Salmi 2016; Vaarama et al. 2014). Utvecklingen tenderar att på olika sätt underminera de sociala villkor som välfärdssamhället vilar på. Problem kring social delaktighet, demokrati och alternativ organisering av social verksamhet har därmed blivit centrala frågeställningar i den aktuella välfärdsdiskussionen.

Studerande som bedriver samhällsvetenskapliga studier behöver lära sig att förhålla sig till en ständigt föränderlig och komplex verklighet. För att utvecklas till en kunnigt handlande professionell är det viktigt att den studerande lär sig att beakta, förstå och granska komplexa samhälleliga förändringsprocessers återverkningar på individnivå. Madsen (2006, 61-62) lyfter fram att det professionella arbetet behöver utövas mot bakgrunden av kunskaper om praxis och dess samhälleliga kontext. Författaren skiljer mellan fyra kunskapsfält, som analyserar det socialpedagogiska arbetet på olika nivåer, och som ger en mer heltäckande förståelse för relationen mellan individ och samhälle. Det samhälleliga kunskapsfältet bidrar till att förstå målgruppen t.ex. barn, unga, vuxna, äldre i ljuset av de förhållanden i samhället som gör människor till socialpedagogiska målgrupper. Samhällets marginaliserings-, utstötnings- och exkluderingsprocesser studeras och problematiseras inom detta kunskapsfält. Det institutionella kunskapsfältet, bidrar med kunskap om hur institutioner skapar möjligheter för individers lärande och utveckling. Det tredje kunskapsfältet som han benämner som det relationella kunskapsfältet berör utveckling av kunskap om relationen och samspelet mellan den professionella socialpedagogen och den enskilda individen och gruppen. Inom det individuella kunskapsfältet igen riktas fokus mot uppkomsten av gemenskaper där individens förutsättningar (t.ex. kvalifikationer) för socialt deltagande analyseras.

I den socialpedagogiska förståelsen är det centralt att se människan i relation till ett sammanhang och därmed blir begreppet delaktighet relevant. Utmärkande för begreppet delaktighet är att det är abstrakt, mångfacetterat och ges varierande innebörder beroende på användningsområde och olika vetenskapliga discipliner (se t.ex. Leemann \& Hämäläinen 2016, 589-92; Isola et al. 2017). I denna artikel utgår vi från en vid definition av begreppet som är främst anknuten till den finländska delaktighetsdiskussionen (se Nivala \& Ryynänen 2019, 138-142), även om internationella referenser ibland används. Begreppet delaktighet används i 
artikeln synonymt med begreppet osallisuus inom finländskt språkbruk, där mångfalden av begreppets betydelser också kan ses som definitionen av begreppet delaktighet. En exakt och allmänt accepterad definition av begreppet saknas fortfarande i Finland (Nivala \& Ryynänen 2013) och begreppet används brett. Det är t.ex. svårt att hitta ett engelskspråkigt ord som inbegriper de olika betydelserna i begreppet osallisuus. Detta betyder också att den finländska förståelsen av delaktighetsbegreppet kan skilja sig från t.ex. den rikssvenska uppfattningen av begreppet, eftersom det inte i någon större utsträckning i Sverige finns en beröring till det finländska breda delaktighetsbegreppet osallisuus.

Vi har i denna artikel valt att närmare undersöka hur socionomstuderande vid professionshögskolan Arcada förstår begreppet delaktighet då de är i slutskedet av sina socionomstudier och skriver sina examensarbeten. Eftersom delaktighetsbegreppet ges en så bred och varierande innebörd i litteraturen, är vi intresserade att studera hur studerande förstått och använt begreppet i sina examensarbeten. Följande frågeställningar har varit vägledande i vår studie: Vilka aspekter av delaktighet lyfts fram i dessa examensarbeten? Inom vilka socialpedagogiska kunskapsfält har dessa delaktighetsaspekter studerats?

Artikeln grundar sig på en kvalitativ dokumentstudie av studerandes examensarbeten under två år (2016-17), där totalt 36 examensarbeten analyserades. Examensarbetet omfattar 15 högskolepoäng och har en uppdragsgivare från olika verksamhetskontexter (t.ex. småbarnspedagogisk verksamhet, skola, flyktingboende, äldreboende). Till sin form kan examensarbetet vara forskningsorienterat eller ett produktutvecklingsarbete (t.ex. att utveckla ett verksamhetskoncept, en handbok, en servicekarta) och skall ha en tydlig anknytning till det sociala verksamhetsfältet, professionen och socialpedagogiken. Avsikten är att de frågeställningar som studeras i examensarbetet har relevans på både en praktisk och lokal samhällelig nivå (jfr Mode 2-forskning i Uggerhøj 2011; Nowotny, Scott \& Gibbons 2001). Examensarbetet erbjuder den studerande möjligheter att integrera vetenskaplig och professionell kunskap (jfr Maaranen 2009) och kan ses som en katalysator för "det goda mötet" mellan högskola och praxis i en samhällskontext (jfr Karlsson 2005).

I de följande avsnitten behandlas begreppet delaktighet, betraktat ur socialpedagogisk synvinkel. Därefter beskrivs studiens material och metod. Resultaten presenteras utgående från dimensionerna deltagande, aktörskap och tillhörighet i begreppet och i relation till de fyra socialpeda- 
gogiska kunskapsfälten. Till slut resonerar vi kring studerandes förståelse av begreppet delaktighet i relation till det socialpedagogiska arbetet och den samhälleliga kontexten.

\section{Delaktighet som deltagande, aktörskap och tillhörighet}

Den grundläggande tanken i den socialpedagogiska förståelsen av begreppet delaktighet är idén om delaktighet som en relation mellan individ och samhälle. Delaktighet förverkligas dels i relation mellan individen och gemenskapen, dels i relation mellan individen och samhället. Att ha möjligheter till att delta i samhälleliga gemenskaper, att agera eller vara en aktiv aktör och även ha en känsla av tillhörighet till olika gemenskaper i samhället utgör centrala förutsättningar för individens upplevelse av delaktighet (se Nivala 2008; Nivala \& Ryynänen 2013; 2019). Betraktat ur socialpedagogisk synvinkel har vi valt i denna artikel att särskilt lägga fokus på ovanstående dimensioner i delaktighetsbegreppet, nämligen till deltagande, aktörskap och tillhörighet, eftersom dessa tre dimensioner utgör centrala byggstenar för förståelsen av begreppet. Utgångspunkten här har varit ett rymligt delaktighetsbegrepp, där det även finns utrymme för att diskutera de tre dimensionerna skilt för sig.

\section{Dimensionen deltagande}

Begreppet delaktighet i betydelsen deltagande granskas vanligen både på samhälls- och individnivå. På samhällsnivå förekommer begreppet ofta i politiska och juridiska styrdokument, som betonar alla människors lika värde med jämlika möjligheter att vara delaktiga och ha inflytande. Om individer eller grupper upplever att de inte kan påverka de egna livsvillkoren och utvecklingen av samhället uppstår maktlöshet och utanförskap. Rätten till delaktighet och inflytande i ett demokratiskt samhälle gäller oavsett ålder, kön, språk, etnisk härkomst, social bakgrund eller förutsättningar (Finlands grundlag 731/1999). Alla medborgare bör ha tillgång till välfärdssamhällets olika institutioner och inga medborgare oavsett funktionsvariation får uteslutas från deltagandet i samhällslivets olika arenor. Statens skyldighet är dels att möjliggöra och dels stöda medborgarnas deltagande i samhället. I detta sammanhang ses delaktighet alltså som en social rättighet och får en ideologisk-politisk innebörd (jfr Molin 2018, 26-27, Nivala 2008, 169). Denna aspekt av delaktighet har förekommit främst i den europeiska samhällsdebatten (se t.ex. Leemann \& Hämäläinen 2016, 1-3). 
I den finländska diskussionen och litteraturen har delaktighet som deltagande främst granskats på individnivå (Leemann, Kuusio \& Hämäläinen 2015) och fokuserat på utvecklandet av servicesystemet och välfärdsservicen (Nivala \& Ryynänen 2013). I det konkreta arbetet har medborgarens delaktighet vanligen berört två aspekter. Den första aspekten tangerar individuellt och kollektivt deltagande vid utveckling av välfärdsservice, medan den andra aspekten handlar om klientens delaktighet i sin egen klientprocess.

För att få reda på hur verksamheten uppfattas av dem som tar del av dessa tjänster har serviceutförare traditionellt samlat in kunskap genom brukarenkäter (jfr passivt och indirekt deltagande i Hultqvist och Salonen 2016). Under senare år har detta sätt bedömts som otillräckligt, och vid planering och genomförande av nationella utvecklingsprogram har det poängterats att en viktig utgångspunkt gällande alla tjänster är, att i allt högre grad beakta brukarnas och anhörigas delaktighet och erfarenhetsexpertis (t.ex. Programmet för utveckling av barn- och familjetjänster LaPe 2016-2018). Det anses alltså numera höra till en allmän kutym att tjänsternas brukare involveras i utvecklingsarbetet för att tjänsternas innehåll bättre ska motsvara de behov som finns. Brukardelaktighetens förverkligande ställer också vissa krav. Brukaren behöver ha erfarenheter av berörda tjänster för att kunna ta ställning till behov och kvalitet på tillgängliga tjänster. Även utbildning för erfarenhetsexperter har ofta ansetts nödvändigt, för att stöda brukaren i att fungera som en representant för den målgrupp hen representerar (se t.ex. Pesäpuu 2019; Voikukkia 2019).

Den andra aspekten berör delaktighet i egen klientprocess, och avser individuellt inflytande vid professionella möten och samtal som berör egna ärenden och beslut. Här formuleras involvering som en rättighet, dvs. rätten att bli hörd, respekterad och att få sina särskilda behov tillgodosedda (jfr t.ex. Lagen om klientens ställning och rättigheter inom socialvården 812/2000, Barnskyddslagen 417/2007, Socialvårdslagen 1301/2014, Lastensuojelun käsikirja n.d.). När det gäller barns rätt till delaktighet i ärenden som berör barnet självt är detta starkt skyddat i lagstiftningen. Olika stegvisa skalor har ofta använts för att belysa graden av individens inflytande i beslutsprocesser (se t.ex. Arnstein 1969; Hart 1992; Shier 2001; Thomas 2007). Madsen (2006, 51-52) talar i detta sammanhang om förhandling - partnerskap, vilket betyder att varje stödinsats och åtgärd behöver planeras i dialog med den berörda.

Det har också förekommit kritik gentemot den ovan beskrivna del- 
aktighetstrenden. Man har ifrågasatt om den offentliga förvaltningens delaktighetssyn i slutändan främst handlar om en positiv retorik, och inte så mycket om brukarnas faktiska inverkan på beslut och processer. I många sammanhang har brukarna fört fram att deras åsikter inte tas $\mathrm{i}$ beaktande på önskat sätt antingen för att beslutandemakten fortsättningsvis starkt hålls hos dem som upprätthåller verksamheten, eller pga. att maktobalansen mellan brukare och professionella är för ojämn (t.ex. en brukarrepresentant bland ett flertal resursstarka styrgruppsmedlemmar). De delaktighetsinriktade verksamhetssätten har också kritiserats för att förminskas närmast till ett rituellt förfaringssätt eller mekaniska verksamhetsmodeller; t.ex. ungdomsfullmäktiges deltagare får delta, men enbart genom att tala och närvara - men inte t.ex. rösta - i ungdomsnämndens möten (Nivala \& Ryynänen 2013, 14-16).

\section{Dimensionen aktörskap}

Upplevelser av delaktighet åstadkoms inte enbart med samhälleliga strukturella möjligheter till deltagande och inflytande i samhällsgemenskaper. För att individen ska kunna utnyttja existerande strukturer och påverkansmöjligheter behöver individen färdigheter att fungera som en aktiv agent eller aktör. (Nivala \& Ryynänen 2013, 26-30, jfr Jyrkämä 2008). Eftersom aktörskapet konstrueras i relationen mellan individen och hens omgivning (Nivala \& Ryynänen 2019, 95) behöver det finnas möjligheter till att individen i en bestämd miljö, i relation till dess givna sociala strukturer, kan göra egna val och beslut gällande eget liv. Aktörskapet byggs upp på basen av vilka förutsättningar det finns för förverkligandet av delaktighet. Utöver yttre strukturella möjligheter behöver individen ha inre förutsättningar att agera. Detta kan relateras till Freires subjektbegrepp; en individ är ett subjekt då hen kan anpassa sig till den omgivande verklighet samt göra kritiska val för att förändra den omgivande verkligheten. (Jfr Nivala \& Ryynänen 2013, 34). I fall individen enbart anpassar sig till beslut gjorda av andra blir hen ett objekt.

Aktörskap är inte en individuell egenskap eller någonting som kan ges människan, inte någonting som händer automatiskt, utan ett resultat av utveckling (se Nivala 2008; Leiman 2013, 32-35). Förverkligande av delaktighet förutsätter att både individens närmiljö och relationerna i den stöder utvecklingen av delaktighetskänslan, och att individen själv har en förmåga att aktivt ta del och vara med i verksamheten, att vara en aktiv aktör (se Nivala 2008, 168-170). Detta är möjligt enbart om individen 
besitter kunskap och en rad färdigheter, t.ex. funktionella färdigheter, sociala färdigheter och färdigheter i att möjliggöra delaktighet även för andra. I praktiken betyder det att hen har grundläggande kunskaper som läs- och skrivförmåga, kunskap om sina formella rättigheter och existerande möjligheter, färdigheter i att sköta ärenden i olika offentliga sammanhang och förmåga att efterlysa sina rättigheter som samhällsmedlem. Det handlar om både individuella färdigheter i att ta vara på möjligheter som erbjuds, och sociala färdigheter för att delta och förankras till den sociala verksamhetsmiljön. (Nivala 2008, 171.) Även Madsen (2001) och Cederlund \& Berglund (2017) anser att individen förutsätts vara utrustad med en rad kompetenser, eller kvalifikationer, som gör att hen kan bemästra dagens krävande livsvillkor och skapa sig en meningsfull tillvaro. För ett fungerande aktörskap krävs förutom förmåga också vilja och motivation hos individen (jfr Jyrkämä 2008; Molin 2004). Enligt Nivala (2008) förutsätter aktörskapet dessutom personlig autonomi, som konkretiseras i självförtroende, karaktärsstyrka och stark självkänsla. Denna personliga autonomi utgör i sin tur en bas för funktionell autonomi, dvs. att individen har tillit till den egna förmågan att kunna ta initiativ, påverka och delta i beslutfattande.

Nivala \& Ryynänen $(2019,203)$ påpekar att aktörskap är någonting som ska stödas, inte förutsättas. Då blir den viktiga frågan: Hur kan individens aktörskap stödas i olika socialpedagogiska verksamhetsmiljöer, i synnerhet i olika institutionella miljöer? Dilemman kan uppstå när det riktas kontroversiella förväntningar på individer; dels förväntas hen anpassa sig till myndighetsåtgärder och organisationens kutym, dels förväntas hen vara en aktiv aktör och ta ansvar över sin situation. En aktiv aktör (klient) är ett handlande subjekt och expert i sitt eget liv, men i praktiken kan hen bli stämplad som en "besvärlig klient". (Närhi, Kokkonen \& Matthies 2013, 25.) Med andra ord tillåts och uppmuntras enbart en viss slags aktörskap. Då ges individen inte möjlighet utgående från egen vilja och förmåga i samspel med andra att göra val och agera i frågor som berör eget liv. Att se och bemöta den enskilda människan som aktör eller åtminstone som en individ som kan och får agera är en central princip i den socialpedagogiska verksamheten (jfr Nivala \& Ryynänen 2019, 95).

\section{Dimensionen tillhörighet}

Utöver deltagande och aktörskap blir även känslan av att höra till ett sammanhang av betydelse för individens upplevelse av delaktighet. Som 
samhällsmedborgare ingår individen i olika former av gemenskaper t.ex. i ett arbetslag, i en skolklass, i en idrottsförening. Men denna formella tillhörighet säger inget om den informella tillhörigheten dvs. subjektiva känslan av att höra till en viss gemenskap (Molin 2004; 2018). Exempelvis kan en individ känna utanförskap trots fysisk hemvist i en viss grupp och besittande av färdigheter för deltagande i gruppen. Om inte tillhörighetshetskänslan infinner sig i sammanhanget blir det svårt att tala om att delaktighet råder. (se Molin 2004, 59). Även Nivala (2008, 172) påpekar att känslan av tillhörighet är starkt anknuten till individens upplevelse av delaktighet.

Enligt May (2013) uppstår känslan av tillhörighet alltid i relation till något - till samhället, andra människor, platser, kulturer eller materiella ting. Författaren talar här om relationella, kulturella och materiella tillhörigheter som tillsammans formar individens uppfattning av hens jag. Individen socialiseras in i en gemenskap, i en kultur som innehåller gemensamma attribut såsom mat, dofter, platser, artefakter. Vidare menar May att individens identitetsskapande sker i relation till likhet men också i relation till skillnader. "We know who we are partly on the basis of knowing who we are not" (May 2013, 79). Vi konstruerar oss själva genom både det som känns lika och det som känns främmande.

En tillhörighet måste vara ömsesidig vilket innebär att individen också behöver få bekräftelse av gruppen om tillhörighet. Närmiljön och nära relationer i den stöder uppkomsten av tillhörighetskänslan. Tillhörighet representerar erkännande, acceptans, känslan av att passa in. "Att känna sig accepterad av en gemenskap kan utlösa känslor av glädje, lycka, bekräftelse, tillit, välvillighet, triumf, engagemang och empati" (Stenberg 2011, 94). Att vara en del av något kan medföra att individen börjar "höra till", att vara en medlem av något större än en själv som ger en känsla av gemenskap och solidaritet. Detta i sin tur leder till självaktning och självrespekt. (Nivala \& Ryynänen 2019, 140.) Icke tillhörighet igen representeras "av känslan av skam, ilska, besvikelse, sorg, svartsjuka, revanschlust och övergivenhet" (Stenberg 2011, 94). Att bli exkluderad ur en gemenskap kan upplevas som mycket smärtsamt och kränkande, vilket också påverkar individens egen självrespekt, tillit till sig själv och psykiska välmående (May 2013). Enligt Nivala \& Ryynänen $(2019,142)$ utgör känslan av den egna betydelsen i ett sammanhang en viktig byggsten i individens välmående. May (2013) påpekar dock att känslan av att inte höra till behöver inte nödvändigtvis innebära en negativ upplevelse. Enligt henne finns alltid en 
spänning mellan att vilja vara lik och känna tillhörighet till andra, och att vilja vara unik och därmed olik andra (May 2013).

Tillhörigheten, som alltid har en stark känslodimension, förändras över tid men är också beroende av situation och sammanhang. May (2013) menar att individen och samhället kontinuerligt påverkar varandra i en dynamisk process, varpå en kontinuerlig social förändring sker. När samhället förändras i sina sociala strukturer och dess medlemmars sätt att relatera till varandra, förändras även individens tillhörighet. Till en viss grad är det möjligt för den enskilde att välja vilka sammanhang hen vill höra till. Yuval-Davis (2011) påpekar ändå att detta till stora delar inte är möjlig, eftersom det finns kollektiva villkor, möjligheter och begräsningar som är socialt och politiskt definierade. Författaren hänvisar i detta sammanhang till begreppet tillhörighetens politik (politics of belonging).

Tillhörigheten kan alltså granskas på både mikro- och makronivå (jfr May 2013, 95-112). Enligt Molin $(2008,41)$ har begreppets komplexa och svårfångade karaktär eventuellt lett till att tillhörighetsaspekten i delaktighetsbegreppet fått en mer undanskymd tillvaro. Ett socialpedagogiskt delaktighetsbegrepp behöver ändå framhålla tillhörighetsdimensionen i människors vardagsliv (se Molin 2018, 39-40).

\section{Material och metod}

För att undersöka socionomstuderandes förståelse av begreppet delaktighet genomfördes en kvalitativ dokumentstudie. I studien granskades socionomstuderandes examensarbeten på bachelornivå, vilka utförts vid professionshögskolan Arcada. Arbeten är skrivna under perioden 2016-17 och offentligt publicerade på Theseus - professionshögskolornas plattform för examensarbeten och nätpublikationer. Det ursprungliga materialet bestod av 54 examensarbeten. En kvantitativ och kvalitativ innehållsanalys (jfr Tuomi \& Sarajärvi 2013) påbörjades genom att göra en tabell över materialet som innehöll examensarbetens titel, år, forskningsområde, målgrupp, verksamhetskontext, metod, typ av examensarbete, teoretisk orientering och förekomsten av begreppet delaktighet. En klassificering och kodning av respektive examensarbete med avseende på ovannämnda aspekter gjordes. Efter genomgången gallrades 18 examensarbeten bort, eftersom delaktighetsbegreppet inte ingick som centralt i dessa examensarbeten. Materialet i den kvalitativa dokumentstudien kom därmed att bestå av 36 examensarbeten.

Den kvalitativa analysen utgick ifrån examensarbetets abstrakt, syfte, 
frågeställning, teoretiska referensram och resultatdiskussion. Stommen för innehållsanalysen utgjordes av dimensionerna deltagande, aktörskap och tillhörighet i begreppet delaktighet (jfr Nivala 2008; Nivala \& Ryynänen 2013; 2019) och de fyra socialpedagogiska kunskapsfälten (Madsen 2006). Studerandes förståelse av begreppet klassificerades i nio kategorier som delades in under de tre dimensionerna deltagande, aktörskap och tillhörighet. En sammanställning av materialet utgående från verksamhemskontext och den dominerande dimensionen $\mathrm{i}$ delaktighetsbegreppet åskådliggörs i tabell 1 .

Tabell 1. Sammanställning av materialet $(n=36)$.

\begin{tabular}{|c|c|c|c|}
\hline VERKSAMHETSKONTEXT & DELTAGANDE & AKTÖRSKAP & TILLHÖRIGHET \\
\hline \multicolumn{4}{|l|}{ Pedagogisk verksamhet: } \\
\hline $\begin{array}{l}\text { Småbarnspedagogisk } \\
\text { verksamhet i daghemsmiljö }\end{array}$ & $1,41,47$ & 5,38 & $23,24,39,40,44,50$ \\
\hline Skolmiljö & 9,16 & $31,35,42$ & 52 \\
\hline \multicolumn{4}{|l|}{$\begin{array}{l}\text { Tjänster för barn, unga och } \\
\text { barnfamiljer: }\end{array}$} \\
\hline Familjearbete & 20 & $17,26,53$ & 2,27 \\
\hline Familjerättsligt arbete & & 11 & \\
\hline Arbete med utsatta ungdomar & & 28 & \\
\hline Barnskyddsinstitution & 29 & & 51 \\
\hline \multicolumn{4}{|l|}{ Tjänster för vuxna: } \\
\hline \multicolumn{4}{|l|}{$\begin{array}{l}\text { Arbetsverksamhet för personer } \\
\text { med funktionsvariation }\end{array}$} \\
\hline Flyktingboende & & & 21 \\
\hline \multicolumn{4}{|l|}{ Tjänster för äldre: } \\
\hline Hemmaboende äldre & $14,22,54$ & & \\
\hline Äldreboende & & 15,43 & 25 \\
\hline ANTAL EXAMENSARBETEN & 10 & 13 & 13 \\
\hline
\end{tabular}


Kännetecknande för de examensarbeten som analyserades är att alla socialpedagogiska målgrupper (barn, unga, vuxna, äldre) finns representerade. Barn med eller utan funktionsvariation har främst studerats i småbarnspedagogisk verksamhet och skolkontext, unga i mottagningshem/barnskyddskontext, vuxna bl.a. i rollen som förälder i småbarnspedagogisk- och i barnskyddskontext, äldre i eget hem eller i äldreboendekontext. Formen på examensarbeten varierade mellan empiriska studier, litteraturstudier och produktutveckling. Utmärkande för dessa arbeten är också att majoriteten av de studerande i sitt kunskapssökande har valt att gå "upptäcktens väg" i stället för "bevisets väg" (jfr Cederlund \& Berglund 2017) för att få svar på frågeställningar som tangerade delaktighet. Det kvalitativa angreppssättet dominerade alltså i de empiriska studierna. När det gäller produktutvecklingsarbeten utgör handböcker eller utvecklande av verksamhetskoncept vanliga produkter.

Studiens empiriska underlag, med 36 examensarbeten, ger rimligtvis en begränsad bild av socionomstuderandes förståelse av begreppet delaktighet, vilket gör att resultaten inte kan generaliseras till andra högskolor med samma utbildningsbakgrund. Även analysförfarandet kan ha haft vissa brister. Vid kategoriseringen var utgångspunkten att välja den dimension i begreppet delaktighet som dominerar, vilket ibland upplevdes utmanande eftersom många examensarbetet till sitt innehåll berörde flera av begreppets dimensioner. Förhoppningsvis ger denna kategorisering trots allt en bild över socionomstuderandes förståelse av begreppet delaktighet.

\section{Socionomstuderandes förståelse av begreppet delaktighet}

I det följande presenteras resultaten som berör socionomstuderandes förståelse av begreppet delaktighet, speciellt deras förståelse av begreppets innebörd i den verksamhetskontext som studerats i examensarbetena. Studiens första frågeställning belyser de aspekter av delaktighet som lyfts fram i dessa arbeten och redovisas utgående från de tre dimensionerna deltagande, aktörskap och tillhörighet i begreppet.

\section{Aspekter av deltagande}

Studerandes förståelse av begreppet delaktighet i betydelsen deltagande är främst relaterad till de yttre förutsättningarna för delaktighet, dvs. till strukturer, normer som ger möjlighet till deltagande i olika sammanhang på mikronivå. Ur materialet steg följande aspekter av deltagande fram: att 
ha tillgång till sociala arenor, att medverka och bli involverad i utvecklingsarbete och att ha inflytande i egen klientprocess. Utmärkande var, att inget av de granskade examensarbetena hade en stark samhällspolitisk vinkling, som skulle ha granskat möjligheter till deltagande i samhället på makronivå (tillgång till arbetsmarknad, tillgång till socialskydd etc.).

Att ha tillgång till olika sociala arenor, även digitala, framträdde som betydelsefulla för skapandet och upprätthållandet av sociala nätverk. Inom kontexten äldreomsorg studerades videosamtal som stöd för äldres delaktighet i samhället. Här ges begreppet delaktighet betydelsen "att ha möjlighet till att upprätthålla och skapa nya sociala kontakter med hjälp av IKT tjänster" (22). Videosamtalen ses som ett sätt att möjliggöra deltagande särskilt för de äldre som bor långt borta från sitt sociala nätverk. Inom småbarnspedagogisk verksamhet behandlades t.ex. personalens tillgång till digitala diskussionsforum, där deltagandet anknöts till "personalens möjlighet att dela med sig av sina tankar och idéer" (1). Från ett föräldraperspektiv på daghem uppfattades också dagliga möten mellan daghemspersonal och föräldrar som en viktig arena i uppbyggandet av delaktighet. Föräldrarnas erfarenhetsbaserad kunskap om daghemmets verksamhet ses som en förutsättning för att kunna påverka och utvärdera verksamheten (47).

Möjligheten till brukarmedverkan och involvering i utvecklingsarbete berördes inom kontexterna hemmaboende för äldre, barnskyddets familjearbete samt skolmiljö $(22,20,16)$. En studie, som tangerade äldres medverkan i utvecklandet av IKT-tjänster, poängterade att äldres erfarenheter behöver tas i beaktande i tjänsteutveckling (22). Medborgarnas rättigheter att bli delaktiga i utvecklingen av tjänster som berör dem själva lyftes också fram i ett arbete som berörde utvecklingen av innovationer inom familjearbetet. "Det är viktigt att sociala innovationsprocessen blir inkluderande och att ivriga familjer som vill vara delaktiga blir hyllade i stället för att förhindra deras viktiga insats" (20). Med hjälp av brukarna kan nya aspekter av deras behov och önskemål tas i beaktande i innovationsprocesser, vilket antas öka tjänstens kvalitet. I ett annat arbete lyftes vikten av att barn med funktionsnedsättning i skolan blir sedda och hörda vid utvecklandet av kommunikationsverktyg. Förutom brukarmedverkan i utvecklingsarbete utgör detta även ett exempel på hur man genom att utveckla behövliga verktyg kan möjliggöra att barnet blir hörd och får inflytande (16).

Delaktighet i betydelsen inflytande i egen klientprocess behandlades i flera arbeten. I en studie som berörde svenskspråkiga äldre med funk- 
tionshinder och deras erfarenheter av service på eget modersmål anknöts begreppet till rätten att delta i planeringen av egen service, i behandlingen av egna ärenden och i utvärderingen av tjänsterna oberoende av funktionsförmåga (54). Ett annat arbete lyfte fram barnets röst i bemärkelsen "barn med funktionshinder ska vara delaktiga i beslut som berör dem själva, i planering av deras vardag och skolgång" (9) och i det tredje arbetet granskades barnet som kapabel och aktiv agent, med fokus på möjligheter att påverka sin vardag (41).

\section{Aspekter av aktörskap}

Studerandes förståelse av begreppet delaktighet i bemärkelsen aktörskap relaterade ofta till den professionellas förhållningssätt, speciellt delaktighetsfrämjande, resursorienterade och dialogiska handlingar. Aktörskapet betraktades utgående från hurdana förutsättningar och möjligheter klienterna har för sitt aktörskap, samt hur de professionella kan förstärka både inre och yttre förutsättningar och samspelet mellan dessa. Med inre förutsättningar syftades till olika kvalifikationer hos klienter och med yttre förutsättningar avses möjligheter och förutsättningar för aktivt aktörskap som fanns i omgivningen, samt hur dessa förstärktes av professionella. Tre aspekter steg fram ur materialet: att skapa förutsättningar för aktörskapet, att förstärka klientens färdigheter och att stöda klientens aktivitet.

Den professionellas betydelse och kompetens då det gäller att skapa förutsättningar för klientens aktörskap behandlades inom flera verksamhetskontexter. Inom kontexten familjerättsligt arbete betonades den professionellas kompetens som skapare av en fungerande växelverkan mellan föräldrar och barn i anslutning till föräldrarnas separation. "Oftast är delaktighet något positivt och är något som t.ex. professionella kan skapa tillsammans med klienten" (11). Inom kontexten småbarnspedagogik anknöts delaktigheten till att professionella ger barn möjligheter att vara aktiva aktörer i sin omgivning: "Genom att tillföra ett socialpedagogiskt perspektiv kan barnen ges möjlighet att själva vara aktörer och bidra till kulturutbudet i närmiliön. Det främjar barnens delaktighet och aktivitet." (5) Inom verksamhetskontexten boende för seniorer beskrevs yttre förutsättningar, såsom personalens erfarenheter av digitalisering och e-hälsa, för att möjliggöra främjandet av den äldres vilja och förmåga till att vara delaktig. "Delaktighet betyder att en människa skall ha både interna och externa förutsättningar för att man skall bli delaktig, det skall bestå av äldres vilja och hens förmåga till att vara delaktig" (15). 
Olika sätt att förstärka klientens färdigheter behandlades i flera arbeten och verksamhetsmiljöer. I ett arbete inom småbarnspedagogik diskuteras hur professionella med hjälp av olika metoder kan förstärka kommunikativa färdigheter hos barn och på så sätt förstärka barns aktörskap. ”De barn som inte kan uttrycka sig verbalt tyckte att bilderna hjälpte dem att berätta och även att välja samtalsämne" (7). I en studie av olika stödmodeller inom familjearbetet konstaterade skribenterna att syftet med dessa är "att utveckla färdigheter, kunskap och rutiner så att föräldrarna själv kan lösa familjens problem i vardagen" (53). Även inom familjearbete lyftes digitala tjänster fram som ett sätt att stärka resurser och aktivitet genom att bidra till reflektion och hjälp till självhjälp hos föräldrarna (26). Inom kontexten boende för seniorer granskas sällskapsdjurens betydelse för de äldres välbefinnande. Djur konstateras fungera som samtals öppnare, vilket ökar chanserna att personer ska inleda samtal. "Klienter får med hjälp av djuren möjlighet att öva sina sociala färdigheter och får på så sätt också lättare att skapa sociala relationer" (43).

Den professionellas roll vid stödandet av klientens aktivitet behandlades inom verksamhetskontexterna familjearbete och skolmiljö. "Man strävar efter att klienten ska fungera som en aktiv och engagerad del av familjearbetet och att nivån på delaktighet ska vara så hög som möjligt” (17). I en studie om barns självkänsla inom verksamhetskontexten skola betonas också olika aktiviteters betydelse för stärkandet av barns självkänsla (31).

\section{Aspekter av tillhörighet}

Studerandes förståelse och användning av begreppet delaktighet i bemärkelsen tillhörighet behandlar olika förutsättningar för att känslan av tillhörighet ska uppstå, i kombination med den professionellas socialpedagogiska handling som stöd i denna process. Att känna samhörighet och gemenskap, att ha gemensamma värderingar samt att bli bekräftad och sedd utgjorde centrala teman i materialet. Inte heller i denna kategori fanns det en uttalad samhällsaspekt, även om några arbeten betonade miljöns och omgivningens betydelse för att skapa en känsla av tillhörighet.

Flera examensarbeten lyfter upp betydelsen av att känna samhörighet och gemenskap som det centrala i delaktighetsskapandet. I en studie som berör inkludering av barn med autism i daghemsgrupp, definieras begreppet delaktighet som "att ta del av något t.ex. en social gemenskap, en uppgift eller en aktivitet eller en daghemsgrupp. Då barn gör något tillsammans t.ex. leker, förekommer också känslan av tillhörighet vilket är en 
viktig aspekt av delaktighet” (23). Pedagogens stöd och förmåga att utgå från barnets perspektiv är här nyckeln i inkluderingsprocessen även för att barn i behov av stöd skall kunna nå känslan av tillhörighet. Känslan av tillhörighet kan förstärkas genom att delta $\mathrm{i}$ aktiviteter som individen upplever som meningsfulla. Denna upplevelse av tillhörighet är alltid subjektiv och kan endast bedömas av personen själv som deltar i aktiviteten. Aktivitetens betydelse för tillhörighetskänslan beskrivs i en studie om musikens betydelse för äldre (25), medan en studie av unga flyktingars upplevelser av det kollektiva boendet som social livsmiljö och som boendeform anknyter främst till känslan av gemenskap och att tillhöra en grupp. "Frihet utan tillhörighet och gemenskap med andra är en frihet utan mening" (21). Gemenskapen får här en meningsskapande betydelse.

Vikten av att skapa eller ha gemensamma värderingar i en grupp betonades i ett flertal arbeten, och blir en förutsättning för att känslan av tillhörighet ska förverkligas. Betydelsen av gemensamma värderingar, gemensam förståelse och gemensamma erfarenheter med tanke på uppkomsten av en tillhörighetskänsla behandlades i daghemskontext och i en barnskyddskontext. I daghemskontext betonades fostringsgemenskapens och den trygga anknytningens betydelse för barnets känsla av tillhörighet $(39,40,44)$, medan liknande erfarenheter beskrevs som gemenskapsskapande faktorer i en studie som berörde ungas boende på institution: "En gemenskap består av ett socialt nätverk var gruppmedlemmar delar gemensamma eller likartade erfarenheter, spenderar tid tillsammans, formar gemensamma värderingar, upplever samhörighet samt framförallt fär positiv bekräftelse av varandra" (51) .

Att bli bekräftad och sedd är en central aspekt för att en känsla av gemenskap och tillhörighet ska uppstå. I en studie som berör mobbningsförebyggande arbete i skolan lyfts betydelsen av bekräftelse av den sociala gemenskapen fram för känslan av tillhörighet. "Att bli bekräftad och sedd är viktigt för varje individ, därför skall ingen i gruppen behöva känna sig utanför gemenskapen" (52). En individ som är socialt inkluderad känner tillhörighet till sociala system. "I en 'rymlig' institution har alla har plats, oavsett särskilda behov. När barnet får förståelse och blir beaktat är chansen större att det känner sig som en del av gruppen." (50).

I figur 1 sammanfattas och illustreras svaret på studiens första frågeställning som belyser de olika aspekterna av delaktighet som lyftes fram i socionomstuderandes examensarbeten. Resultaten visar att aspekterna som berör dimensionerna deltagande och tillhörighet i delaktighets begreppet 
är främst relaterade till ett klientperspektiv dvs. vad deltagande och tillhörighet betyder ur klientens synvinkel. Aspekterna som tangerar aktörskap igen avgränsar sig till ett professionsperspektiv dvs. hur professionella i olika verksamhetsmiljöer kan stöda och stärka klientens aktörskap.

\section{DELAKTIGHETENS OLIKA ASPEKTER}

DELTAGANDE

Ha tillgång till sociala arenor

Bli involverad $\mathrm{i}$ utvecklingsarbete Ha inflytande i egen klientprocess KLIENTPERSPEKTIV

\section{AKTÖRSKAP}

Skapa förutsättningar för aktörskap

Förstärka klientens aktörskap

Stöda klientens aktivitet

PROFESSIONSPERSPEKTIV

\section{TILLHÖRIGHET}

Känna samhörighet och gemenskap

Ha gemensamma värderingar

Bli bekräftad och sedd

KLIENTPERSPEKTIV

Figur 1. Aspekter av delaktighet inom dimensionerna deltagande, aktörskap och tillhörighet

\section{Delaktighetsaspekternas anknytning till de fyra kunskapsfälten}

Inom vilka socialpedagogiska kunskapsfält har då de olika aspekterna av delaktighet studerats? Genom att spegla ovanstående resultat mot de fyra socialpedagogiska kunskapsfälten (Madsen 2006) eftersträvades en mera heltäckande bild över socionomstuderandes förståelse av begreppet delaktighet (se figur 2).

Inom det samhälleliga kunskapsfältet är studerandes förståelse av begreppet delaktighet i betydelsen deltagande främst relaterad till de yttre förutsättningarna för delaktighet på individnivå, dvs. till strukturer och normer som erbjuder tillfällen till deltagande i olika sammanhang. Deltagandet handlade i dessa fall om att stöda och möjliggöra deltagande via sociala arenor för olika målgrupper i samhället samt att tillvarata servicebrukarens erfarenhetsexpertis i utveckling av välfärdsservicen. Däremot tangerade studerandes examensarbeten inte samhälleliga marginaliserings-, utstötnings- och exkluderingsprocesser dvs. orsaker som medverkar till individers behov av socialpedagogiska insatser i vardagslivet.

Ett stort antal av studierna placerade sig inom det institutionella kunskapsfältet. Institutioner och organisationer definierar i stor utsträckning ramarna för det professionella arbetet. Betydelsen av professionell kompetens då det gäller att skapa förutsättningar för klientens aktörskap lyftes 
särskilt fram. Professionella sågs som skapare av en fungerande växelverkan och som ger utrymme för individens aktiva aktörskap och inflytande i egen livsplanering. Att skapa och fungera enligt gemensamma värderingar ansågs viktiga med tanke på uppkomsten av individens känsla av tillhörighet $\mathrm{i}$ institutionella gemenskaper.

Relationens och det sociala samspelets betydelse för klientens upplevelse av delaktighet beskriver studerandes förståelse av begreppet inom ramen för det relationella kunskapsfältet. Att bli bekräftad och sedd är viktigt för varje individ och påverkar känslan av tillhörighet. Bekräftelsen bör ges av både den professionella och de andra deltagarna som deltar i verksamheten. Stödandet av klientens aktivitet och aktörskap underlättas i sin tur med hjälp av en fungerande och bekräftande relation.

Vad gäller det individuella kunskapsfältet tar studierna främst fasta på individens känsla av tillhörighet och behövliga individuella färdigheter för att fungera i samhället. I studierna fokuserades speciellt på den professionellas roll vid stärkande av individuella färdigheter i olika verksamhetskontexter. Även den professionellas socialpedagogiska handlingar i form av t.ex. aktiviteter blir betydelsefulla för uppkomsten av individens känsla av gemenskap och samhörighet, vilket bidrar till upplevelser av delaktighet.

\section{SAMHÄLLELIG NIVÅ}

- Ha tillgång till sociala arenor (deltagande - klientperspektiv)

- Bli involverad i utvecklingsarbete (deltagande - klientperspektiv)

\section{INSTITUTIONELL NIVÅ}

- Ha inflytande i egen klientprocess (deltagande - klientperspektiv)

- Skapa förutsättningar för klientens aktörskap (aktörskap - professionsperspektiv)

- Ha gemensamma värderingar (tillhörighet-professionsperspektiv)

\section{RELATIONELL NIVÅ}

- Bli bekräftad och sedd (tillhörighet - klientperspektiv)

- Stöda klientens aktivitet (aktörskap - professionsperspektiv)

\section{INDIVIDUELL NIVÅ}

- Känna samhörighet och gemenskap (tillhörighet - klientperspektiv)

- Förstärka klientens färdigheter (aktörskap - professionsperspektiv)

Figur 2. De olika delaktighetsaspekternas anknytning till de fyra kunskapsfälten 


\section{Diskussion}

Syftet med studien har varit att undersöka socionomstuderandes förståelse av begreppet delaktighet vid professionshögskolan Arcadas socionomutbildning under åren 2016-17. Genom att klassificera examensarbetena beroende på var tyngdpunkten i beskrivningen av de olika dimensionerna av delaktighet låg var strävan att skapa en förståelse för hur studerandena har förstått och använt begreppet i olika sammanhang. Många examensarbeten till sitt innehåll berörde en eller två av begreppets dimensioner och det blev intressant att se hur studerandena i sina arbeten uppfattat att dessa dimensioner av delaktighet är relaterade till varandra. Vanligen behandlades flera dimensioner av begreppet, t.ex. anknöts aktörskap till deltagande eller till tillhörighet i många arbeten utan att studerandena mera ingående reflekterade kring detta. Däremot förekom det inte arbeten där alla tre dimensionerna skulle ha varit relaterade till varandra.

Resultaten visar också att flertalet av socionomstuderandes examensarbeten speciellt lyfter fram frågeställningar som berör delaktighet ur ett professionsperspektiv inom det institutionella, relationella och individuella kunskapsfältet. Exempelvis är studerandes förståelse av begreppet delaktighet i bemärkelsen aktörskap ofta relaterad till den professionellas förhållningssätt, speciellt stödjande och resursförstärkande handlingar i olika verksamhetsmiljöer. Klienten ses här alltså som ett "föremål" för stödåtgärder och inte som aktiv aktör. Den professionellas tolkningsföreträde gällande aktörskapets innehåll och uttryck problematiseras inte ur en politisk/ideologisk synvinkel; aktörskap definieras och "ges" av den professionella, istället för att "tas" av den utsatta som en social rättighet. Frågeställningar som tangerar klienters förverkligande av eget aktörskap i dessa examensarbeten dvs. klientperspektivet uteblev i detta fall. När det gäller delaktighet i betydelsen tillhörighet är studerandes förståelse av begreppet anknuten till olika förutsättningar (t.ex. att bli bekräftad och sedd) för att känslan av tillhörighet skulle uppstå, i kombination med den professionellas socialpedagogiska handling som stöd i denna process. Känslan av tillhörighet förverkligades här främst i relation till den omedelbara närmiljön och inte till samhället i stort. Studerandes förståelse av begreppet i betydelsen deltagande är främst relaterad till de yttre förutsättningarna för delaktighet, dvs. till strukturer, normer som ger möjlighet till deltagande och inflytande i olika sammanhang t.ex. i egen klientprocess eller i utveckling av stödåtgärder (klientperspektiv). Klienterna betraktades som deltagare i förhållande till samhället genom 
olika tjänster. Däremot studerades inte processer och strukturer som hindrar eller skapar möjligheter för deltagande i ett allt mer förändrat samhällsliv.

Bland de examensamensarbeten som granskats finns det alltså en starkare koppling till delaktighet på individ- och gruppnivå än på samhällspolitisk nivå. En förklaring här kan handla om att socialpedagogisk handling i många avseenden hänför sig till människors vardagsliv i bred mening (jfr Bolin och Molin 2018, 185). Bolin och Molin $(2018,186)$ konstaterar, att vardagslivet ändå inte borde ses som avskilt från samhällsstrukturen, eftersom vi genom att fokusera på strukturer som har betydelse för hur vardagslivet tar sig uttryck kan förstå strukturella villkor som också påverkar människans situation. Att kritiskt studera samhällets institutioner, strukturer och processer och dess påverkan på individen och hens situation uppfattas av t.ex. Ryynänen (2017) som central i det socialpedagogiska tänkandet. Frågan är hur denna strukturella kritiska dimension uppmärksammas hos de professionella i de verksamhetskontexter där delaktighet studerats, eller om den finns där men inte lyfts fram i socionomstuderandes examensarbeten. En annan fråga är hur väl utbildningen, som traditionellt starkt fokuserat på det relationella arbetet, lyfter fram den globala och samhälleliga nivån i socialpedagogiskt arbete. I fortsatta studier kunde en fråga vara: Hur ser de professionella på strukturella trenders inverkan på det egna arbetet och klientgruppernas livssituation?

I inledningen konstaterades att studerande som bedriver samhällsvetenskapliga studier behöver lära sig att förhålla sig till en ständigt föränderlig och komplex verklighet och problematisera samhällets utstötningsoch exkluderingsprocesser. Grundläggande tankar i den s.k. kritiska socialpedagogiken (se Nivala och Ryynänen 2019) är vikten av dialogisk och kollektiv verksamhet, att synliggöra samhällets olika maktkonstellationer, samt betydelsen av en sådan verksamhet som baserar sig på jämlikhet och ställer sig på de svagas sida. Såväl studerande som professionella behöver alltså ständigt utmanas till att från individnivån "höja blicken" och uppmärksamma sammanhangets betydelse och att också arbeta på en strukturförändrande nivå, dvs. att vara en världsförändrare som "gör skillnad" i människors liv (jfr Nivala \& Ryynänen 2019). 


\section{REFERENSER}

Abrahamsson, H. 2011. Globaliseringens lokala uttryck. Städer som noder för global samhällsstyrning eller som slagfält för sociala konflikter? En essä kring lokal globalisering, folkbildning och socialt hållbar stadsutveckling inför den nationella folkbildningskonferensen "Folkhälsa, hållbar utveckling och global rättvisa" Malmö den 14.6.2011. Tillgänglig http://www.gu.se/digitalAssets/1337/1337548_ globaliseringens.pdf (hämtad 4.4.2019).

Arnstein, S. R. 1969. A ladder of citizen participation. Journal of the American Institute of Planners 35, 216-224.

Barnskyddslagen 417/2007. Tillgänglig http://www.finlex.fi/sv/laki/ ajantasa/2007/20070417 (hämtad 23.10.2018).

Blomgren, J., Hiilamo, H., Kangas, O. \& Niemelä, M. 2012. Growing Inequalities. Country Report for Finland November 2012. Tillgänglig http://www.gini-research.org/system/ uploads/609/original/CR-Finland-v2.pdf (hämtad 7.11.2018).

Bolin, A. \& Molin, M. 2018. Epilog: Socialpedagogisk handling - förutsättningar, utmaningar och möjligheter. I A. Molin \&. A. Bolin (red.) Socialpedagogisk handling i teori och praktik. Rapport nr 2108:4. Trollhättan: Högskolan Väst, 185-188.

Cederlund, C. \& Berglund, S-A. 2017. Socialpedagogik: pedagogiskt socialt arbete. Stockholm: Liber.

Finlands grundlag 731/1999. Tillgänglig http://www.finlex.fi/sv/laki/ ajantasa/1999/19990731 (hämtad 7.11.2018).

Hart, R. A. 1992. Children's participation: From tokenism to citizenship. Innocenti essays, United Nations Children's fund 4, 3-39.

Hultqvist, S. \& Salonen, T. 2016. Brukardelaktighet i välfärdsstaten - retorik och praktik. I V. Denvall, C. Heule \& A. Kristiansen (red). Social mobilisering - en utmaning för socialt arbete. Malmö: Gleerups utbildning AB, 49-64.

Isola, A-M., Kaartinen, H., Leemann, L., Lääperi, R., Schneider, T., Valtari, S. \& KetoTokoi, A. 2017. Mitä osallisuus on? Osallisuuden viitekehystä rakentamassa. Helsinki: Terveyden ja hyvinvoinnin laitos.

Jyrkämä, J. 2008. Toimijuus, ikääntyminen ja arkielämä: hahmottelua teoreettismetodologiseksi viitekehykseksi. Gerontologia 22 (4), 190-201.

Karlsson, P-A. 2005. En lärande organisation? Examensarbetet som katalysator för "goda möten" mellan skola och högskola. Didaktikens Forum 2 (1), 7-15.

Karvonen, S., Martelin, T., Kestilä, L. \& Junna, L. 2017. Tulotason mukaiset terveyserot ovat edelleen suuria. Suomen sosiaalinen tila 3/2017. Helsinki: Terveyden ja hyvinvoinnin laitos.

Karvonen, S. \& Salmi, M. (toim.) 2016. Lapsiköyhyys Suomessa 2010-luvulla. Työpaperi 30/2016. Helsinki: Terveyden ja hyvinvoinnin laitos.

Kestilä, L. \& Karvonen, S. (toim.) 2019. Suomalaisten hyvinvointi 2018. Helsinki: Terveyden ja hyvinvoinnin laitos. 
Lagen om klientens ställning och rättigheter inom socialvården 812/2000. Tillgänglig http://www.finlex.fi/sv/laki/ajantasa/2000/20000812 (hämtad 11.11.2018).

Lastensuojelun käsikirja n.d. Helsinki: THL. Tillgänglig https://thl.fi/fi/web/ lastensuojelun-kasikirja (hämtad 12.11.2018).

Leemann, L., Kuusio, H. \& Hämäläinen, R-M. 2015. Sosiaalinen osallisuus. Sosiaalisen osallisuuden edistämisen koordinaatiohanke (Sokra). Helsinki: Terveyden ja hyvinvoinnin laitos. Tillgänglig www.thl.fi/sokra (hämtad 15.10.2018).

Leemann, L. \& Hämäläinen, R-M. 2016. Asiakasosallisuus, sosiaalinen osallisuus ja matalan kynnyksen palvelut. Pohdintaa käsitteiden sisällöstä. Yhteiskuntapolitiikka $5,568-594$.

Leiman, M. 2013. Avuttomuus ja toimijuus. Tuetusta toimijuudesta itsenäiseen toimijuuteen. Dialoginen ohjaus ja neuvonta käytännössä. Polku työmarkkinoilleosahanke. Tillgänglig https://www.elykeskus.fi/documents/10191/1506373/ Dialoginen+ohjaus+ja+neuvonta/c1637dbb-3feb-447f-938d65eb0bca1198 (hämtad 24.11.2018).

Maaranen, K. 2009. Practitioner research as part of professional development in initial teacher education. Teacher Development 13 (3), 219-237.

Madsen, B. 2001. Socialpedagogik. Lund: Studentlitteratur.

Madsen, B. 2006. Socialpedagogik: integration och inklusion i det moderna samhället. Lund: Studentlitteratur.

May, V. 2013. Connecting self to society: belonging in a changing world. Basingstoke: Palgrave Macmillan.

Molin, M. 2004. Att vara i särklass: om delaktighet och utanförskap i gymnasiesärskolan. Doktorsavhandling vid Institutet för handikappvetenskap. Linköping: Linköpings universitet.

Molin, M. 2008. Delaktighet i olika världar - om övergången mellan gymnasiesärskola och arbetsliv. Forskningsrapport vid Högskolan Väst, 2008:2. Trollhättan: Högskolan Väst.

Molin, M. 2018. Framväxten av ett socialpedagogiskt delaktighetsbegrepp. I A. Molin \&. A. Bolin (red.) Socialpedagogisk handling i teori och praktik. Rapport nr 2108:4. Trollhättan: Högskolan Väst, 19-47.

Nivala, E. 2008. Kansalaiskasvatus globaalin ajan hyvinvointiyhteiskunnassa. Kansalaiskasvatuksen sosiaalipedagoginen teoriakehys. Väitöskirja. Kuopio: Snellman-instituutti.

Nivala, E. \& Ryynänen, S. 2013. Kohti sosiaalipedagogista osallisuuden ideaalia. Sosiaalipedagoginen aikakauskirja 14, 9-41.

Nivala, E. \& Ryynänen, S. 2019. Sosiaalipedagogiikka. Kohti inhimillisempää yhteiskuntaa. Helsinki: Gaudeamus.

Nowotny, H., Scott, P. \& Gibbons, M. 2001. Re-thinking science. Knowledge and the public in an age of uncertainty. Cambridge: Polity. 
Närhi, K. \& Kokkonen, T. \& Matthies, A-L. 2013. Nuorten aikuisten miesten osallisuuden ja toimijuuden reunaehtoja sosiaali- ja työvoimapalveluissa. Teoksessa M. Laitinen \& A. Niskala (toim.) Asiakkaat toimijoina sosiaalityössä. Tampere: Vastapaino, 113-145.

Pesäpuu 2019. Lapset ja nuoret kehittäjinä. Jyväskylä: Pesäpuu ry. Tillgänglig: https:// pesapuu.fi/koulutukset/lapsetjanuoret/ (hämtad 10.10.2019).

Programmet för utveckling av barn- och familjetjänster LaPe 2016-2018. Tillgänglig https://stm.fi/sv/spetsprojekt/barn-och-familjetjanster (hämtad 3.8.2018).

Ryynänen, S. 2017. Emancipation as a social pedagogical concept. Föreläsning 7.10.2017 på NUFS-konferens i Helsingfors.

Shier, H. 2001. Pathways to participation: Openings, opportunities and obligations. Children \& Society 15, 107-117.

Sjöberg, S. \& Turunen, P. 2018. Samhällsförändringar som utmanar. I S. Sjöberg \& P. Turunen (red.) Samhällsarbete: aktörer, arenor och perspektiv. Lund: Studentlitteratur, 45-64.

Socialvårdslagen 1301/2014. Tillgänglig http://www.finlex.fi/sv/laki/ ajantasa/2014/20141301 (hämtad 12.11.2018).

Stenberg, H. 2011. Gemenskapens socialpsykologi. Malmö: Liber.

Thomas, N. 2007. Towards a Theory of Children's Participation. The International Journal of Children's Rights 15, 199-218.

Tuomi, J. \& Sarajärvi, A. 2013. Laadullinen tutkimus ja sisällönanalyysi. Helsinki: Tammi.

Uggerhøj, L. 2011. What is practice research in social work: definitions, barriers and possibilities. Social Work \& Society 9 (1), 45-59.

Yuval-Davis, N. 2011. The Politics of Belonging. Intersectional Contestations. Thousand Oaks: Sage.

Vaarama, M., Karvonen, S., Kestilä, L., Moisio, P., Muuri, A. (toim.). 2014. Suomalaisten hyvinvointi 2014. Helsinki: Terveyden ja hyvinvoinnin laitos.

Voikukkia 2019. Kokemusasiantuntijat mukaan toimintaan? Tillgänglig: https:// www.voikukkia.fi/ammattilaiset/kokemusasiantuntijan-hyodyntaminen/ (hämtad 10.10.2019). 
60 - Sosiaalipedagoginen aikakauskirja, vuosikirja 2019, vol. 20 